PART 2

Exacerbated Violence at the Local Level 
$\Longrightarrow$ Taylor \& Francis

Taylor \& Francis Group

http://taylorandfrancis.com 


\title{
4
}

\section{EMPOWERMENT OR IMPOSITION?}

\section{Extractive Violence, Indigenous Peoples, and the Paradox of Prior Consultation}

\author{
Philippe Le Billon and Nicholas Middeldorp
}

\section{Introduction}

The rapid growth of resource sectors over the past two decades has seen many policies seeking to address the harmful effects of extractive activities on environments and communities (Feichtner et al., 2019). Environmental impact assessments (EIAs), corporate social responsibility (CSR) programs, sustainability principles, and the consultation of affected communities have become part of governance tools making land "investable" for extraction (Le Billon and Sommerville, 2017). Many of these instruments—-such as EIAs, Human Rights Impact Assessments, and CSR - have come under critique for legitimizing and reproducing extractivist logics and praxis (Brock and Dunlap, 2018).

Here, we focus on the paradox of prior consultation and extractive violence: while Indigenous peoples supposedly benefit from rights to prior consultation over extractive projects, they are still disproportionately facing the various forms of violence associated with extraction (Comisión Interamericana de Derechos Humanos, 2015; Global Witness, 2019). To help to explain this paradox, we examine the role of the practice of prior consultation in advancing extractive projects rather than its envisioned ideal of enforcing compliance with Indigenous and environmental human rights, which would ensure free, prior, and informed consent (FPIC) by affected communities if obtained before project execution. Many governments, corporations, and international development agencies have now accepted prior consultation of local communities and, in particular, Indigenous ones as a prerequisite for the implementation of "extractive" projects— a term referring to mining and hydrocarbons extraction, but also more broadly to high-impact, land-based projects including conservation (which might require displacement) and renewables as well as large-scale infrastructure projects such as agri-business, hydropower, solar energy, ports, or highways. Project proponents pragmatically see prior consultation as a 
mechanism to avoid costly conflicts and preempt some of the most violent aspects of land-based development projects (e.g. Food and Agriculture Organization of the United Nations., 2014; GIZ, n.d.).

The prior consultation of local and, in particular, Indigenous communities thus appears as a prominent constituent of progressive forms of extractive governance, while a lack of FPIC is often presented as a root cause of conflict (Global Witness, 2019). Many studies denounce the inadequacies of prior consultation processes (e.g. Flemmer and Schilling-Vacaflor, 2016), the non-recognition of consent as a legal requirement (Miller, 2015; Perreault, 2015), the depoliticization effects of bureaucratic consultation processes (Merino, 2018; Urteaga-Crovetto, 2018), and the often "abysmal disparities in power and resources between the actors involved" (Rodríguez-Garavito, 2011, p. 305). Few studies, however, have attempted to systematically examine how consultation processes contribute to "extractive violence."

By extractive violence, we mean violence associated with extractive logics and projects. Seeing violence as more than an "act" or "consequence," we approach violence as an unfolding process (Springer and Le Billon, 2016), which instils fear, hurts, or lowers the "level of needs satisfaction below what is potentially possible" for both the human and non-human (Galtung and Fischer, 2013, p. 35). From this perspective, the concept of extractive violence allows us to consider the various violent dimensions of prior consultation, including those that could result from the anticipation of future (even if uncertain) project implementation (Groves, 2017). As argued below, prior consultation processes cannot be separated from the violence of dispossession, repression, and pollution, including through their effects on health, livelihoods, wellbeing, culture, and sense of belonging. We therefore argue that prior consultation cannot be counted upon as a panacea for avoiding socio-environmental conflict. Unless principles of free, prior, and informed consent are more stringently implemented, prior consultation does little to avoid "extractive violence" at best and could cloud and actually deepen extractive violence at worst.

Our conceptual framework and discussion of the violence of prior consultation is based on a review of 68 studies. These studies were selected through the following process: first, a general identification using the search terms "prior consultation," "consent," "participation," and "FPIC" in three languages (English, Spanish, and Portuguese) and through two search engines (Google Scholar, Web of Science); and second, a selection of studies relevant to the focus of this review (i.e. academic studies of consultation processes examining the wider context and impacts of consultation, rather than publications discussing its technicalities, which are amply found in the gray literature). Of the 68 selected studies, 53 were published in English, 12 in Spanish, and three in Portuguese. Out of this total, 28 discuss one or more case studies, others discuss the application of prior consultation nation-wide, cross-examine or compare practices of prior consultation between countries, or discuss the legal basis and implications of the right to prior consultation in the countries and regions under research. The selected studies represent contributions from a broad range of disciplines, including anthropology, geography, development studies, sociology, political science, and (international) law. (The full literature review chart can be found here: https://bit.ly/34CIvyW.) 
All studies except for one were published over the past decade, reflecting the recent and rapid rise in attention for this topic. Two-thirds of the studies empirically focused on Latin America, reflecting the high level of scholarly attention on prior consultation in that region, a high incidence of conflicts over extractive and infrastructural projects, and widespread (nominal) acceptance of the need to consult Indigenous peoples - in addition to slight bias in languages used in our search. The rest include studies on cases in Australia (Walsh et al., 2017), Canada (e.g. Youdelis, 2016; Moore et al., 2017), Germany (Brock and Dunlap, 2018), India (Choudhury and Aga, 2020), the Philippines (Young, 2019), Sub-Saharan Africa (e.g. Ece et al., 2017; Inkman et al. 2018; Mitchell and Yuzdepski, 2019), and the United States (Miller, 2015). Although the findings of this review are largely based on studies empirically focused on Latin America, we observed that findings of studies from other regions, regardless of whether consulted populations are Indigenous or not, were largely consistent with the negative experiences documented in Latin America.

In addition to this scholarly literature, we also selected and reviewed gray literature, including policy recommendation reports, prior consultation guidelines, and reports by non governmental organizations (NGO) (e.g. Global Witness) and human rights institutions (e.g. Interamerican Commission of Human Rights). This review is also informed by insights gained through participant observation and group discussions in three subregional forums organized by the Instituto Interamericano de Derechos Humanos (IIDH) on the experiences of prior consultation with a total of 70 Indigenous leaders from 18 Latin American countries in 2015, as well as field research and work visits by Philippe Le Billon across Latin America on socio-environmental conflict and Indigenous rights (both as academic researcher and as NGO consultant). These include visits to Indigenous communities resisting extractive projects seeking to usurp ancestral lands in Honduras; interviews in Guatemala and Honduras with local actors for a proposed environmental justice project by the IIDH; workshops on intercultural justice in Guatemala, Chiapas, and Oaxaca with operadores de justicia (judges, Ombudsman staff, public defence lawyers, public attorneys) debating prior consultation; field research in Nicaragua's Caribbean coast on resistance to the proposed Interoceanic Canal project following a fraudulent consultation process; and a field visit to the Colombian Amazon, where a micro-hydropower plant was imposed on the Vaupés River in Indigenous territory, destroying sacred sites. During these visits, the lead author spoke with a range of actors, including Indigenous leaders and activists, private sector representatives, as well as state officials such as Ombudsman staff, Environmental Ministry staff, and operadores de justicia.

Following this introduction, we first review debates around extractive violence in relation to consultation and indigeneity and then discuss relations between prior consultation and extractive violence. The paper concludes with suggestions for further research and practical recommendations. 


\section{Extractive Violence, Indigenous Peoples, and Consultation Processes}

Extractive violence has three main dimensions. First is the violence of dispossession, often "compensated" with cash payments, temporary jobs, and "alternative" livelihoods marked by their unfairness, their uneven allocation, and the false "equivalences" they seek to create between incomparable entities across incommensurable ontological and epistemic differences (Leifsen et al., 2017). Thus, dispossession can be both material and ontological, through the delinking of communities from their territories, facilitated by the appeal or imposition of capitalist modernity and the environmental degradation that renders traditional livelihoods increasingly unviable. Here, Indigenous deterritorialization runs parallel with state/company-led (re)territorialization, as a mutually imbricated process (Di Giminiani, 2015).

Second, the violence of coercion often is exercised on local communities to impose extractive activities, especially when resistance to projects takes a more organized shape (Navas et al., 2018; Middeldorp and Le Billon, 2019); when clashes occur within or between communities over granting consent (Jaskoski, 2020) such as the case of elite abuse (Vermeulen and Cotula, 2010); or when projects are forcibly imposed despite consent refusal (Steinberg, 2016). If coercion is often understood as direct threats or use of physical violence, we understand it as also taking many other forms, including deception, manipulation, and corruption consolidating the dominance of extractive regimes, affecting decision-making within and by Indigenous communities (Cariño, 2005; Nest, 2017).

Third are the physiological and psychological harms associated with the pollution and degradation of socio-environmental systems resulting from extractive activities, including temporally dispersed "slow violence" that is often "invisible," such as insidious health risks for communities exposed to pollution (Nixon, 2011) and "ecological violence" against the non-human within Indigenous territories (Navas et al., 2018).

These three dimensions help to sketch out the outcomes of extractive projects for concerned communities and to understand their relations with prior consultation processes. As discussed below, prior consultation can be interpreted as a soft instrument of dispossession, which involves some forms of coercion and frequently results in exposure to pollution and other socio-environmental impacts as projects often end up being implemented despite a lack of consent.

\section{Indigenous Peoples and Extractive Frontiers}

Indigenous peoples are social groups self-identifying as distinct from the settler population and who, "irrespective of their legal status, retain some or all of their own social, economic, cultural and political institutions" (International Labour Organization, 2009, p. 49). At the cores of many Indigenous peoples' cosmovisions and ways of life are their reciprocal relationships with the land and territories both shaped by and confronting historical and contemporary colonial processes (Wildcat et al., 2014). The relational attachment among Indigenous peoples, their territory, 
and the non-human beings that might inhabit it (Youdelis, 2016) is what gave birth to the right to prior consultation in the first place-Indigenous peoples demand control over their lands and prior consultation was envisioned as a guarantee mechanism (Comisión Interamericana de Derechos Humanos, 2015) - but it is also in part why they are disproportionately affected by extractive violence.

Indigenous peoples are frequently located in extractive frontiers, with their territories being considered by settlers and extractive companies as sparsely populated and underused "resource rich" or "critical infrastructure" areas (Pasternak, 2017). The extractivist logic of exploiting natural resources, implemented in territories inhabited by communities who are predisposed not to exploit land, water, or other livelihood means on an industrial basis, means that Indigenous peoples often face the brunt of environmental degradation and its polluting effects (Moore et al., 2017) and become the first line of opposition against extractive projects (Urkidi, 2011). Here, the claim of rights to consultation and consent is frequently central to the struggles that result from extractive projects. We note that these two terms often are confused or purposively misused by project proponents replacing consent (i.e. obtention of a voluntary agreement) with consultation (i.e. providing project information and/or obtention of an opinion).

According to the Environmental Justice Atlas, 48 percent of the conflicts over extraction around the world involved Indigenous groups or traditional communities, with half of these conflicts resulting in the criminalization or other forms of repression, including assassinations (Temper et al., 2015). Between 2014 and 2018 alone, at least 276 Indigenous people were killed while peacefully seeking to protect their land and environment, representing a third of the total number of defenders recorded (Global Witness, 2019). Indigenous peoples are also disproportionately affected considering their supposed right to refuse the forceful imposition of extractive projects. In many countries, and in contrast with other population groups such as non-indigenous agrarian communities, Indigenous peoples officially have stronger land and resource use rights. Not only does it appear that these rights are not well respected, but also, the denial of such rights could result in greater levels of violence against Indigenous peoples, including through prior consultation processes.

\section{A Brief Overview of "Prior Consultation"}

ILO Convention 107 (1957), the earliest international attempt to grant rights to Indigenous peoples, described their condition as "less advanced" (art. 1) and was highly assimilationist. In the context of the rise of Indigenous rights movements and acknowledgements in the 1970s and the 1980s, its successor, ILO Convention 169 (1989) moves away from the assimilationist standpoint and acknowledges Indigenous self-determination, including the right to prior consultation. Prior consultation of Indigenous peoples is considered a legal obligation for the twenty countries that ratified ILO Convention 169 and is now widespread within processes around extractive projects involving Indigenous communities. UNDRIP, 
the United Nations Declaration for the Rights of Indigenous Peoples (United Nations, 2007, art. 32), although not legally enforceable, progressively considers obtaining FPIC through the mechanism of prior consultation as a key requirement for the implementation of extractive projects.

In the Americas, based on its interpretation of Article 21 (the right to property) of the American Convention of Human Rights (1969), the Inter-American Court of Human Rights issued landmark decisions with pueblo Saramaka vs. Surinam (2007) and pueblo Kichwa de Sarayaku vs. Ecuador (2012), holding the states of Surinam and Ecuador responsible for the violation of the right to free, prior, and informed consultation (these decisions remain ambiguous about the meaning and legal requirement of obtaining consent) regarding extractive industries operating in Indigenous territories, creating jurisprudence for future cases (Instituto Interamericano de Derechos Humanos, 2016). Prior consultation has become common practice in much of Latin America: with the notable exceptions of El Salvador and Panama, C169 is adopted by all Latin American countries with Indigenous populations, and in some cases, as in Peru, the consulta previa is also integrated into national legislation (Urteaga-Crovetto, 2018). Canada also recognizes the duty to consult Aboriginal peoples, although the notion of a veto is rejected (Mills, 2017).

In Sub-Saharan Africa, a debate on prior consultation is emerging (Roesch, 2016), but experiences are scarce. Many African governments were hesitant to accept UNDRIP, fearing that it would encourage tribalism, ethnic violence, and secessionist movements (Mitchell and Yuzdepski, 2019). The concept of "Indigenous" is also disputed in a continent where most ethnic groups lay a claim to autochthony (ibid). However, the African Commission, borrowing heavily from jurisprudence from the Interamerican Court of Human Rights (leading authors to frame FPIC in Africa as a legal transplant (Roesch, 2016) progressively ruled in 2010 that the nomadic Endorois people (Kenya), displaced in the name of conservation, in their condition as Indigenous people have collective rights to territory and to FPIC, setting a legal precedent for future cases. Nonetheless, the ruling remained ambiguous on whether it is the state's duty merely to seek or also to obtain consent (Inkman et al.,2018). Ten years later, implementation of prior consultation procedures remains the exception rather than the rule in Sub-Saharan Africa, but the concept has entered the vocabulary of communities and NGOs supporting them in the struggle against dispossession induced by mining, conservation, and other industries (Roesch, 2016).

The UN program REDD+ and many multinational companies also pursue prior consultations, in part to address human rights standards and reputational risks concerns. Although some CSR principles are not entirely clear about this, UNDRIP and ILO Convention 169 place the obligation to consult firmly in the hands of the state-not the involved private company (Doyle, 2014). Generally speaking, where prior consultation is not a legal obligation, the procedure appears to be carried out more often by the private company itself, following CSR principles such as the IFC's Performance Standards or the RSPO (Roundtable on Sustainable Palm Oil) prior consultation guidelines, as seen in Canada where consultations are commonly delegated to project proponents as well (Moore et al., 2016). 
Mainstream views on public consultation generally recognize three at times overlapping components: notification, which simply informs the public; consultation proper, which seeks to gain the perspectives of members of the public; and participation, which actively involves the public in decision-making over the formulation of the project and its approval (Rodrigo and Amo, 2006). Beyond these general components, prior consultation processes dealing with Indigenous peoples need to be culturally appropriate, inclusive, and integrated with social and environmental impact studies (United Nations, 2013). The notion of consent refers to the permission granted by the public for the project, and thereby constitutes a principle that is more substantive than narrow interpretations of participatory rights (Rodrigo and Amo, 2006). For consent to be valid, several principles need to be followed, with permission being granted through free will (i.e. absence of coercion), in full knowledge of the possible consequences, and prior to the implementation of the project. However, as the next section will show, prior consultation is in practice often wrought with violent dimensions.

\section{Extractive Violence and Prior Consultation}

Building on critiques of prior consultation processes, we identify five main ways through which violence can permeate prior consultation processes.

\section{Ongoing Colonialism}

The first violent process within prior consultation lies in a wider context of ongoing and often unacknowledged colonialism - symbolic violence in Bourdieu's terms (1979), or ontological violence according to Escobar (2015). The framework of settler colonialism is rarely used outside the Anglo-context (for Latin America, see Speed, 2017), but alternative conceptualizations such as internal colonialism exist (Iturralde, 2015). Contemporary colonialism is visible in the lack of acknowledgement of Indigenous rights, lack of basic service provisioning in Indigenous communities, ongoing land conflicts with settlers, ongoing racism and negative stereotyping, and the undermining or outright negation of alternative ways of living (Simpson, 2017). A notable aspect of ongoing colonialism in the context of prior consultation is the imposition of state law and the non-recognition of customary or Indigenous law and jurisdiction, along with the dismissal of the validity of Indigenous cosmovisions (De la Rosa Rondón, 2017) and traditional environmental knowledge (Baker and Westman, 2018).

\section{Denial of Prior Consultation}

The second violent process associated with prior consultation is the non-recognition of Indigenous status or territorial rights of affected communities. This symbolic form of violence affects identity rights. The denial of internationally or domestically prescribed consultation rights constitutes a violation in practice of the law and a betrayal of the 
political processes that allowed for these rights to be legally recognized in the first place. In Sub-Saharan Africa, despite the African Commission's conceptualization of Indigenous Peoples as self-identifying as such, having a connection to the land, and being in state of marginalization/dispossession versus other groups, the category of Indigenous remains contested by groups in power (Mitchell and Yuzdepski, 2019). In Canada, Metís communities continue to face difficulties in being recognized as Aboriginal (Mills, 2017). In Colombia, where legislation has recognized collective land rights and consultation rights for Indigenous and Afro-Colombian groups, government authorities and extractive companies have argued that communities and their territories could not be considered "Indigenous" once communities had resettled in new areas, even though displacement was often the result of paramilitary actions; or that there were too few Indigenous or Afro-Colombian people in a community to remain Indigenous, even if in-migration was the primary cause of demographic changes (Rodríguez, 2009). In Peru, the government has hired private consultants with the intention to demonstrate the non-Indigenous status of communities (Urteaga-Crovetto, 2018). Not only does this deny the right to consultation, but also, it actively denies Indigenous identities and the right to self-identification more broadly, with implications for entitlements, territorial claims, and group survival.

\section{Limited Scope of Prior Consultation}

A third problem associated with efforts to limit the scope of consultations, and to force Indigenous peoples into the legal formalism and technicalities of a (settler) colonial juridical realm (Rodríguez-Garavito, 2011). Peru is unique in adopting a law on free, prior, and informed consultation (Law 29785, of 2011), but UrteagaCrovetto (2018, p. 10) points out that the law has "proceduralized" consultation, masking power asymmetries in the absence of state neutrality-while provisions specifying the right to consent (the right to veto a project) were completely taken out of the law (Flemmer and Schilling-Vacaflor, 2016). In some cases, consultations end up being simply a provision of (partial and biased) information on the part of the company and government (Alzate, 2019). The resulting misperception of projects and their impacts by communities can later result in frustration, as well as a sense of exploitation, especially when a lack of corporate disclosure results in greater exposure to harm (Helwege, 2015). These experiences are not exclusive to the Global South nor to Indigenous peoples, as Walsh et al., (2017, p. 167) show in their study of community consultation of a non-indigenous community in Australia regarding mining: "community members felt their livelihoods and landscapes were being destroyed and felt powerlessness to stop or change the project." The scope and technicalities of consultation processes could also result in insufficient support for meaningful participation (Perreault, 2015). This could include translation issues, funds to finance counter-expertise, or time pressures denying communities the time they need to decide. Consultation and consent can also be limited to minor project dimensions, take place at too late a stage in its design, and not be renewed when significant changes-including the extension of activities-are 
planned (Weitzner, 2002). In turn, these experiences can bring about deeper grievances and motivate an escalation of protests against companies and government authorities (Conde and Le Billon, 2017).

\section{Biased Selection of Consulted Individuals and Communities}

A fourth violent process is associated with the biased selection of communities and community members involved in consultation processes. The scope of a project's impact is not determined by the affected people, but by the company and the EIA it has commissioned-possibly leaving entire communities out (Baker and Westman, 2018), while the cumulative impact of different extractive projects is often not considered (Mills, 2017). Local elites frequently take advantage of consultation processes to secure private gains, often facilitated by extractive companies aiming to cultivate mutually profitable relations with local politicians and customary authorities. For example, across Sub-Saharan Africa, cases have been documented of customary authorities abusing their power and circumventing democratic processes for private gain (Roesch, 2016; Ece et al., 2017; Hundsbæk Pedersen and Kweka, 2017). Co-optation of community members and/or local authorities, including payments of per diems, contracts, jobs, and outright bribery not only undermine principles of political representation weakening local democracy (Ece et al., 2017) but also exacerbates intra-community wealth inequalities and tensions. When multiple leadership structures exist, states and companies take advantage to consult those that suit their needs, as currently playing out in Western Canada in the disputes between hereditary chiefs and Band Councils (accountable to the government) over the construction of pipelines through Indigenous lands (Sterrit, 2019). Gender inequality is also a major concern. Sekar (2016, p. 113) studying a case of prior consultation surrounding forestry-induced displacement of a tribal people in India, observed that "the voices of women and some socially marginalized individuals are systematically neglected during discussion." A strong male bias was also found in consultation processes in Latin America (Instituto Interamericano de Derechos Humanos, 2016), while the social impacts of extractive industries are often gendered (The WoMin Collective, 2017). As expressed by a Peruvian female participant in a regional forum held in 2015:

those who are affected by the disasters [the mining projects], are the women. The men can take their backpacks and leave, looking for work. But the women cannot leave that easily because we have our children, we have our animals to look after. ... But it is a sacrifice to make, to be visible, to be heard, to be consulted. It was not easy to enter into these spaces of dialogue, because they [the men] did not want to give us the microphone.

Participation biases and the associated exacerbation of inequalities can contribute to creating and/or fuelling conflicts within and between communities. The exclusion of some community members or authorities from consultation processes through 
stigmatization, criminalization, and physical repression constitute major forms of violence. For example, in the context of prior consultation for the Nicaraguan Interoceanic Canal, the state directly interfered in Indigenous elections, and took away the legal status of an oppositional Afro-descendant communal government while granting it to a newly founded parallel one headed by Sandinista party members (personal observation, February 2017). As distrust in institutional channels grows, more people engage in protest actions to get their voices heard and interests recognized.

\section{Coercive Imposition of Project Despite Lack of Consent}

Finally, there is the violence of imposing a project despite its rejection by affected communities. This dimension includes slow and ecological forms of violence, structural violence associated with inequalities and relative deprivation resulting from extractive activities and revenue (mis)distribution, and direct forms of violence and repression, for example as a result of mine area extension. Although currently published research does not systematically account for the number of cases in which projects are implemented without consent, no single case or country study reviewed in this paper found state/company recognition of binding consent or veto rights, and there are signs that its consequences for increased social protest opposing large scale projects seem well established across many jurisdictions (Hanna et al., 2016a). In Honduras, even the murder of Indigenous activists against the Agua Zarca hydroelectric dam initially did not stop the involved European development banks from backing the project, using an unsubstantiated discourse of FPIC as legitimization (Middeldorp and Le Billon, 2019).

Once a project has started, a lack of appeals process and independent dispute resolution mechanisms exacerbates grievances among communities, which could incite direct action in the form of protests, blockades, and sabotage. Despite the risk of repression, protesters generally see such forms of mobilization as legitimate and necessary to obtain respect for their rights (Hanna et al., 2016b). Opponents of extractive projects not only face the direct physical violence of security forces during protests, but also threats, criminalization, and physical abuses, including assassination (Global Witness, 2019). Government authorities often impose a "state of emergency," restricting civil rights and intensifying (sometimes deadly) repression as documented by Young (2019) in the Philippines, further legitimizing these actions through the parallel promotion of restricted "dialogue" processes (Taylor and Bonner, 2017). Across the political spectrum, Indigenous rights defenders are often framed as opponents of "development" or "the public interest," and they are sometimes criminalized for doing so (Birss, 2017; Doran, 2017, Graddy-Lovelace in this volume). Following this effort to map out the potential violence of prior consultation processes, we turn to the main ways in which prior consultation processes can unfold, using possible outcomes based on two sets of variables: whether authorities and extractive companies launch a prior consultation process or not, and whether communities have a strong or weak capacity to organize themselves politically to provide or withhold consent. 


\section{Indigenous Peoples and Prior Consultation Scenarios}

The relative strength of Indigenous institutions, including their level of internal unity and agreement over decisions, political advocacy capacity, and ability to rally external support are key in demanding prior consultation (Schilling-Vacaflor and Flemmer, 2015), while their willingness to accept extractive projects is key in the negotiation of project benefits (Torres-Wong, 2019). The willingness of communities to accept or oppose extractivism depends on many factors, including the relative success of local livelihood strategies such as agriculture or artisanal mining (Orozco and Veiga, 2018) and the level of (dis)trust in the state and concerns over health and socio-environmental impacts-often informed by prior experiences (Conde and Le Billon, 2017).

\section{Assessing the Record of Prior Consultation in Latin American Countries}

As mentioned above, prior consultation is most widely put in practice in Latin America, although the debate around prior consultation and FPIC is emerging in Sub-Saharan and South and South-East Asian contexts. In this section, we specifically provide an overview of experiences with prior consultation in Latin America.

Following an extensive study on prior consultation in Bolivia, Mexico, and Peru, Torres-Wong (2019) found that these states consistently choose not to implement prior consultation regarding mining projects due to expected resistance and that consultation processes are only helpful to Indigenous communities that support extractivism and seek to obtain project benefits. Looking at consultation outcomes in these countries between 2007 and 2017, Zaremberg and Torres-Wong (2018) note that, to their knowledge, prior consultation procedures have not once succeeded in halting undesired extractive projects. However, they contend that prior consultation is "not completely without use in resource-based conflicts" (ibid, p. 44): it lowers the propensity and intensity of state repression, and it allows for pecuniary benefits when Indigenous communities and their institutions are well-organized and willing to negotiate.

While prior consultation processes employed as a "soft tool" to impose extractive projects can reduce the likelihood and intensity of direct forms of violent repression (which more frequently takes place when communities reject both the project and the consultation process from the onset), they can simultaneously promote other forms of violence associated with inter- or intra-community tensions over biased participation and benefit-sharing mechanisms (Peterson St-Laurent and Le Billon, 2015), as well as the "slow violence" of environmental degradation resulting from the legitimization of extractive projects implemented, even without final consent (Nixon, 2011; Holterman, 2014).

There is no equivalent systematic study to that conducted by Zaremberg and Torres-Wong (2018) conducted on Bolivia, Mexico, and Peru. Yet, the literature on prior consultation in Latin America broadly confirms their findings (Comisión 
Interamericana de Derechos Humanos, 2015; Wright and Tomaselli, 2019). Latin America is also the world region where the right to consultation is most widely embraced. However, Latin America is likely the world's most conflictive region in terms of extractive violence. Out of 2,584 environmental justice conflicts recorded across the world by the Environmental Justice Atlas, 770 conflicts were located in Latin America. The region also accounted for 72 percent of reported killings of land and environmental defenders worldwide between 2002 and 2018, althoughlike for EJAtlas - this could in part reflect a higher level of reporting compared to other regions (Global Witness, 2019).

While some Latin American states made progress with the implementation of FPIC (e.g. use of Indigenous languages in administrative decisions, education reforms, and proposed legal reforms), its effective implementation falls behind with regards to "strategic industries" such as infrastructure and extractive projects. The principle of FPIC is consistently violated as governments, across the political spectrum, follow (neo)extractivist development models giving precedence to resource extraction, hydroelectric projects, and large-scale plantations with inadequate or no consultation (Instituto Interamericano de Derechos Humanos,, 2016).

Peru and Colombia are two key cases to consider. Peru adopted a law on prior consultation in 2011, but Urteaga-Crovetto (2018, p. 10) points out that the law has "proceduralized" community consultation, masking power asymmetries in the context of the absence of state neutrality. Provisions on the right to consent were completely taken out of the law; and Doyle (2019) points towards serious implementation flaws favouring the interests of corporations. Despite these serious flaws and Indigenous discontent, this law now stands as a model for law proposals in both Honduras and Guatemala (field visit to Guatemala and Honduras, March 2018), processes facilitated by the German development cooperation GIZ (n.d.). These law proposals do not count on support of the Indigenous peoples themselves.

In Colombia, consultation processes have been consistently applied in the last decade despite the lack of a specific law, as they are rooted in a progressive constitution (Alzate, 2019) and a series of Constitutional Court rulings that have led to a strong jurisprudence on the subject matter (Instituto Interamericano de Derechos Humanos, 2016) which nonetheless remain ambiguous about binding consent. According to the Ethnic Groups department of the Defensoría del Pueblo (Colombia's human rights ombudsman) 8,560 consultations have taken place up to 2017 , of which 1,585 in 2017 alone. However, the agency lacks the capacity to supervise the majority of consultas meaning that the state, in practice, functions as a mere observer of company-led processes. Furthermore, the right to a veto is not recognized, as expressed by the Ethnic Groups Ombudsman himself: "we are a developing country ... is it fair that 3 percent of the population holds 28 percent of the subsoil riches?... we cannot move ahead without exploiting" (personal communication, February 9th, 2018), implying with his answer that the duty to obtain consent before exploiting natural resources would mean an impediment to the development process. 
At forums in 2015 Indigenous leaders from Bolivia, Nicaragua, and Venezuela denounced the co-optation of Indigenous institutions by the state by offering private benefits, or the creation of Indigenous governing organizations parallel to the preexisting ones. Guatemala, Honduras, Peru, Colombia, and Mexico were associated more strongly with threats directed at opposition leaders and the militarization of strategic territories. These contexts of violence were also directly related to prior consultation procedures by Padilla Rubiano (2015) in Guatemala, Llanes-Salazar (2020) in Mexico, and Weitzner (2019) in Colombia. In this context, whether dealing with right-wing or left-wing governments, indigenous rights defenders frequently face stigmatization - being framed as opponents of the public interest of development - as well as criminalization. So far, no study has been conducted that maps the full scale of criminalization of human rights defenders on a regional level. However, it seems to be a widespread phenomenon, with indigenous rights defenders held captive as political prisoners for claiming their rights to territory (Global Witness, 2019). In Ecuador and Chile for example, dozens to hundreds of indigenous rights defenders have been jailed or are facing criminal charges for participating in demonstrations (Doran, 2017). In the years before her murder in 2016, Honduran activist Berta Cáceres was both stigmatized (framed as a murderer in national media) and criminally accused. In April 2018, Guatemalan anti-mining activist Abelardo Curup was sentenced to 150 years in prison for a crime that he claimed he did not commit and died in prison shortly thereafter (Prensa Comunitaria, 2018). In countries otherwise affected by high impunity rates, legal systems function with great efficiency when employed to criminalize rights-claiming populations (Doran, 2017). In addition to the lack of meaningful consultation, female indigenous leaders note that the social impacts of extractive industries are often gendered (The WoMin Collective, 2017) and emphasize that they often have to struggle to have their voices heard as decision-makers and especially as rights defenders, including within their own communities (Instituto Interamericano de Derechos Humanos,, 2016, p. 67).

\section{Conceptualizing Prior Consultation Outcomes}

Building on our literature review and field observations, we identify eight major possible prior consultation outcomes based on whether prior consultation is taking place as well as the organizing capacity of communities and their willingness to provide consent (see Table 4.1). We understand the organizational capacity of communities as reflecting a number of variables such as the number of affiliates, the quality of leadership and institutions, the mobilization of supporters and allies, as well as the broader political and repressive contexts - such as the democratic or authoritarian character of the state-in which community responses take place.

Based on the objectives of mainstream prior consultation, Outcome 5 represents a so-called "win-win" for companies and communities, whereby the interactions between communities with a strong Indigenous organizing capacity and consultation procedure followed in good faith by all parties result in consent being 
TABLE 4.1 Prior consultation outcomes

\begin{tabular}{|c|c|c|}
\hline $\begin{array}{l}\text { Community } \\
\text { characteristics }\end{array}$ & Prior consultation & No prior consultation \\
\hline $\begin{array}{l}\text { Strong Indigen- } \\
\text { ous organizing } \\
\text { capacity + } \\
\text { opposition to } \\
\text { the project }\end{array}$ & $\begin{array}{l}\text { Outcome 1a: cancellation or 1b: } \\
\text { impasse } \\
\text { The project is cancelled or stalled as } \\
\text { no agreement is reached. Possible } \\
\text { Indigenous strategies: reconsider the } \\
\text { project and its benefits (Outcome 5) } \\
\text { or opt for social mobilization (Out- } \\
\text { come 2). The impasse is likely to } \\
\text { fuel internal divisions, exploited by } \\
\text { the state or private company, who } \\
\text { could opt for repression to weaken } \\
\text { Indigenous institutions (Outcome } \\
\text { 3); co-optation to influence decision- } \\
\text { making (Outcome 5) or a combi- } \\
\text { nation (Outcome 7). }\end{array}$ & $\begin{array}{l}\text { Outcome 2: confrontation } \\
\text { The project tries to move for- } \\
\text { ward without prior consultation } \\
\text { and/or without consent, but } \\
\text { social mobilization halts or dis- } \\
\text { rupts the project, the protest } \\
\text { often being legitimized through } \\
\text { a discourse of the right to FPIC. } \\
\text { Could lead to a cycle of protest } \\
\text { and repression, which could } \\
\text { lead to project cancellation. } \\
\text { Unlikely to lead to compensa- } \\
\text { tion and project benefits. } \\
\text { Examples: Middeldorp and } \\
\text { Billon, } 2019 \text {. }\end{array}$ \\
\hline
\end{tabular}

Weak Indigenous organizing capacity + opposition to the project

Strong Indigenous organizing capacity + consent
Examples: Jaskoski, 2020; Young, 2019; Merino, 2018; RodríguezGaravito, 2011.

\section{Outcome 3: manipulation}

The project moves forward despite the lack of consent. The weak position of the Indigenous community vis-à-vis the state and the company is exploited: the consultation procedure is (ab)used to channel and contain discontent and satisfy legal requirements. Unlikely to lead to compensation and project benefits.

Examples: Alzate, 2019; Choudhury and Aga, 2020; Brock and Dunlap, 2018; Ece et al., 2017; Marston and Perreault, 2017; Walsh et al., 2017; Padilla Rubiano, 2015; Navarro Smith, et al., 2014; Castillo Meneses, 2012.

\section{Outcome 5: collaboration}

The project moves forward after consent is obtained. The consultation procedure is followed in good faith by all parties who negotiate a fair compensation and benefit-sharing agreement.

Examples: Torres-Wong, 2019.

\section{Outcome 6: risking future conflict}

The project moves forward without prior consultation and without initial objections, but could face protests once it is operational, as a pressure mechanism to obtain compensation and/or a benefit-sharing agreement, or due to unforeseen negative impacts. Protests could in turn be responded to with repression.

Example: Middeldorp et al., 2016. 
TABLE 4.1 (Cont.)

\begin{tabular}{lll}
\hline $\begin{array}{l}\text { Community } \\
\text { characteristics }\end{array}$ & Prior consultation & No prior consultation \\
\hline $\begin{array}{l}\text { Weak Indigen- } \\
\text { ous organizing } \\
\text { capacity }+\end{array}$ & $\begin{array}{l}\text { Outcome 7: an unfair deal } \\
\text { consent }\end{array}$ & $\begin{array}{l}\text { Outcome 8: exclusion } \\
\text { consent is obtained. The consultation } \\
\text { process is treated as a mere adminis- } \\
\text { trative procedure, and power imbal- } \\
\text { ances, including possible cases of } \\
\text { corruption within Indigenous insti- } \\
\text { tutions, are exploited by the state/ } \\
\text { company to avoid (fair) compensa- } \\
\text { regardless of Indigenous atti- } \\
\text { tudes toward the project. Unli- } \\
\text { tion and benefit-sharing. }\end{array}$ \\
& $\begin{array}{l}\text { Examples: Vermeulen and Cotula, } \\
\text { 2020; Schilling-Vacaflor and Flem- }\end{array}$ & \\
& mer 2015; Perreault, 2015. & \\
\hline
\end{tabular}

Source: Authors.

obtained together with a fair compensation and benefit-sharing agreement between communities and project proponents. However, our literature review suggests that this outcome is often not materialized.

With the exception of Outcome 5 and Outcome 1a, if indeed the company and government respect the denial of consent, all other scenarios entail situations that violate the FPIC principle. These could leave communities with uncompensated negative livelihood impacts; including in cases where prior consultation is denied as a result of symbolic violence or structural violence (e.g. denial of Indigenous status or of "significant" impact requiring consultation by biased licencing institutions). As further discussed in the next section, prior consultation processes can thus be considered as being part and parcel of extractive violence.

\section{Rejecting or Reforming Prior Consultation?}

As Merino (2018, p. 82) warns in his analysis of prior consultation in Peru, Indigenous demands run the risk of "ending in an institutional vacuum or reproducing social conflicts by providing social actors with no option but to step aside from the participatory game." Merino fears that conflicts will re-emerge, because prior consultation as a participatory mechanism has failed to give Indigenous peoples a relevant voice in environmental governance. Through successful use of the court system, Indigenous people have in some cases managed to temporarily halt extractive projects due to improper or lack of consultation, as documented by Xiloj (2019) in Guatemala But given the lack of court-acknowledged veto power, the right to prior consultation is increasingly rejected by the intended beneficiaries themselves: several Indigenous peoples, across different countries, have declared they no longer wish to be consulted. Examining resistance by Indigenous groups to prior consultation processes around five extractive conflicts within Colombia, Jaskoski (2020, pp. 1-2) found different 
strategies: trying to obtain environmental protection prior to the arrival of extractive industries, avoiding prior consultation altogether; denouncing the lack of prior consultation when they were excluded from it; and challenging the legitimacy of the prior consultation process when consultation was limited to project proponents; or refusing to engage in the mandatory consultation procedure altogether. A member of Colombia's U'wa declared with strong words during a forum attended in October 2015:

We do not want a prior consultation, they do not have reason to ask us, because we do not have the right to a veto. If they don't respect the ultimate decision of the people, why negotiate mother earth, why negotiate life, negotiate the territory? So the consultation would be like, how would you, as a people, like to die? By knife? By the bullet? Expropriated? In this moment that is how we think of it. What we want is to live, and to live with dignity. The territory is our life, and that is where we feel we are alive, where we give continuity to our uses and customs. ....while [the government] doesn't respect [the ILO 169] Convention, we will not accept a consultation process.

Some communities have organized alternative consultation processes (Doyle and Cariño, 2013), mostly through self-organized "popular consultations." Such consultas comunitarias or consultas populares have mostly taken place in Latin America, notably in Guatemala and Peru, often with the objective of demonstrating local opposition to large-scale mining (McNeish, 2017; Walter and Urkidi, 2017) and, increasingly, hydroelectric projects (observation in Honduras and Guatemala, March/April 2018). Originally used by Indigenous peoples claiming the right to FPIC, other rural populations (who lack the legal right to prior consultation) have also started to use this mechanism with great success, as recently shown in the Cajamarca case in Colombia (McNeish, 2017).

One difference between official prior consultations and popular ones is that the latter frequently takes place prior to project development - with, for example, the objective of declaring a region as a "no-go" area for extractives projects-while official prior consultations, ironically, often take place ex post project approval. While prior consultation is under state or company control-and thus subject to colonialist logics and manipulation as detailed in this chapter-popular consultation takes place in an arena where involved communities seek to exercise their autonomy and claim the territory. Studies of popular consultations have pointed at outcomes ranging from "changes in project design to political agenda setting, and the opening of spaces for participation and public debate" (Dietz, 2019, p. 145).

States, however, often do not recognize the legal validity of popular consultations and thus seek to delegitimize them as symbolic moves on the part of externally manipulated populations. While popular consultations can be understood as a promising alternative, their political potential needs to be understood as either part of the broader realm of "participatory governance" paradigm, as the strength of popular consultations mostly emerges from contexts of liberal policies of participation, or as 
part of Indigenous and community autonomy paradigms and law (Xiloj, 2019). In this respect, popular consultations might be a more successful instrument than mainstream prior consultation to prevent or counter extractive violence. Yet, at least two caveats need to be considered. One is that popular consultations also point to the shortcomings of, or increasing discontent with, formal electoral democracy, as it questions the legitimacy of the territoriality of the nation-state (Haesbaert, 2013), with a possible outcome of entrenching sectarian forms of communalism. Second, some popular consultations have themselves been criticized for erasing divergent views within communities (Walter and Urkidi, 2017), hinting at intra-community coercion within these processes.

\section{Conclusion: Taking Violence Out of Prior Consultation}

Prior consultation, as enshrined in ILO Convention 169 and UNDRIP, is hailed as a tool of conflict prevention, participation, and benefit sharing. In most cases, consultation processes are considered the responsibility of the state. Nonetheless, this chapter has shown that in practice, states ignore their obligation to respect the human right to consultation, particularly discarding free, prior, and informed consent. As Torres-Wong (2019, p. 144) argues, "in a context of persistent and deep economic inequality and generalized violence, it should come as no surprise that the implementation of the right to prior consultation has failed to protect Indigenous territories in the ways envisioned by its most forthright advocates." Prior consultation is thus often an act of window dressing which has dire consequences for both livelihoods and lives (Wright and Tomaselli, 2019).

National development policies remain guided by the interests of the extractive and infrastructure sectors, which often are in contrast with the needs and cosmovisions of Indigenous communities. As a result, the historical marginalization of Indigenous peoples persists, with distrust often characterizing their relation to states that reproduce a colonial logic well into the twenty-first century. In this context, prior consultation processes are either denied altogether due to lack of recognition of Indigenous status or land title, or are characterized by power asymmetries and top-down "informing of project intentions." All too often, limits are placed on who is consulted through geographical scope, the co-optation of community leaders, as well as gender biases. Furthermore, the abundance of CSR standards and principles has not filled the gap between theory and practice and, if left unchecked, could be used strategically to legitimize projects lacking meaningful consultation.

The disregard for the principle of FPIC contributes to the historical marginalization of Indigenous peoples, who depend on their access to land and natural resources for the continuation of their livelihood and culture. From the Indigenous side, negative experiences with prior consultation have led to an increase of rejection of the entire process and have encouraged the pursuit of alternative self-organized "popular" consultations. Many Indigenous rights defenders have turned to protest actions that are commonly responded to with stigmatization, criminalization, and direct violence. This 
situation of disrespect for Indigenous human rights, in turn, raises questions about the substantive quality of nominally democratic states.

Our objective here is not to reject prior consultation processes altogether, but to point to their commonly biased instrumentalization, as well as their violent dimensions and counterproductive effects. Nor is it our intent to dismiss the political and emancipatory potential of political mobilization around consultation processes (see Rodríguez-Garavito, 2011). Indeed, formal participatory instruments can have significant potential when combined with other Indigenous-led strategies and organizational processes (Green, 2014; Machado et al., 2017). The non-implementation of the right to consultation can itself constitute an opportunity for political organization and resistance. Furthermore, as argued by Leifsen et al. (2017), other participatory mechanisms and practices around extractive activities, rather than prior consultation alone, need to be considered in order to capture a more complex picture, which is beyond the scope of this paper. Finally, a more comprehensive analysis would also examine how prior consultation relates to environmental justice. This should not only be in terms of its three main classical dimensions-recognition as a "stakeholder," participation in decision-making and distribution of the burdens of extraction - but also in terms of a decolonial and transformative environmental justice based on Indigenous "pillars of self-governing authority, the undoing of the ontology of land as property, and epistemic justice" (Temper, 2019, p. 108). As a result, the scope of this paper is limited by its object (prior consultation) and its conceptual framework (extractive violence).

There is a need for scholars, in collaboration with communities affected by extractive industries, to envision and put into practice alternatives to state- or company-led prior consultation. Torres-Wong (2019) calls for the exploration of alternative mechanisms to channel anti-extractivist demands. The popular consultation is one such mechanism, albeit community-led and often not legally recognized. It explicitly rejects the state- or company-led process: whereas the latter is used as an instrument of control, popular consultation is a form of resistance and a claim of autonomy. But what can be done to reconstruct the consultation process itself as a fundamental Indigenous right recognizing veto power? Promoting rights awareness, independent monitoring, legal aid, and accompaniment is fundamental to reduce the abuse of power by state institutions, companies and local leaders. Finally, we believe that a strengthening of the (inter)national legal system is paramount, including the ability to hold transnational companies complicit in depriving Indigenous peoples of their rights and make them legally accountable for doing so.

\section{References}

Alzate, L. (2019) 'Prior consultation as a scenario for political dispute: A case study among the Sikuani Peoples from Orinoquía, Colombia' in Wright, C. and Tomaselli, A. (eds.). The Prior Consultation of Indigenous Peoples in Latin America: Inside the Implementation Gap. London: Routledge, pp. 91-105. 
Baker, J.M. and Westman, C.N. (2018) 'Extracting knowledge: Social science, environmental impact assessment, and Indigenous consultation in the oil sands of Alberta, Canada', The Extractive Industries and Society, 5, pp. 144-153.

Birss, M. (2017) 'Criminalizing environmental activism: As threats to the environment increase across Latin America, new laws and police practices take aim against the frontline activists defending their land and resources', NACLA Report on the Americas, 49 (3), pp. 315-322.

Bourdieu, P. (1979) 'Symbolic power', Critique of Anthropology, 4(13-14), pp. 77-85.

Brock, A. and Dunlap, A. (2018) 'Normalising corporate counterinsurgency: Engineering consent, managing resistance and greening destruction around the Hambach coal mine and beyond', Political Geography, 62, pp. 33-47.

Cariño, J. (2005) 'Indigenous peoples' right to free, prior, informed consent: Reflections on concepts and practice', Arizona Journal of International \& Comparative Law, 22, pp. 19-39.

Choudhury, C. and Aga, A. (2020) 'Manufacturing Consent: Mining, Bureaucratic Sabotage and the Forest Rights Act in India', Capitalism Nature Socialism, 31 (2), pp. 70-90.

Comisión Interamericana de Derechos Humanos. (2015) 'Pueblos indígenas, comunidades afrodescendientes, industrias extractivas', $C I D H-O E A$. Available at: www.oas.org/es/ cidh/informes/pdfs/industriasextractivas2016.pdf.

Conde, M. and Le Billon, P. (2017) 'Why do some communities resist mining projects while others do not?', The Extractive Industries and Society, 4 (3), pp. 681-697.

De la Rosa Rondón, M.G. (2017) 'Inobservancia del derecho a la consulta previa', Revista Jurídica Mario Alario D’Filippo, 8 (16).

Di Giminiani, P. (2015) 'The becoming of ancestral land: Place and property in Mapuche land claims', American Ethnologist, 42 (3), pp. 490-503.

Dietz, K. (2019) 'Direct democracy in mining conflicts in Latin America: Mobilising against the La Colosa project in Colombia', Canadian Journal of Development Studies/Revue canadienne d'études du développement, 40 (2), pp. 145-162.

Doran, M. (2017) 'The hidden face of violence in Latin America. Assessing the criminalization of protest in comparative perspective', Latin American Perspectives, 44 (5), pp. 183-206.

Doyle, C. and Cariño, J. (2013) 'Making free prior \& informed consent a reality: Indigenous Peoples and the extractive sector', Indigenous Peoples Links (PIPLinks), Middlesex University School of Law, and The Ecumenical Council for Corporate Responsibility.

Doyle, C.M. (2014) Indigenous Peoples, Title to Territory, Rights and Resources: the Transformative Role of Free Prior and Informed Consent. London: Routledge.

Ece, M., Murombedzi, J., and Ribot, J. (2017) 'Disempowering Democracy: Local Representation in Community and Carbon Forestry in Africa', Conservation and Society, 15 (4), pp. 357-370.

Environmental Justice Atlas. (n.d.) World Map. Available at: https://ejatlas.org/.

Escobar, A. (2015) 'Territorios de diferencia: La ontología política de los "derechos al territorio", Cuadernos De Antropología Social, 41, pp. 25-38.

Food and Agriculture Organization of the United Nations. (2014) Respecting free, prior and informed consent. Practical guidance for governments, companies, NGOs, Indigenous peoples and local communities in relation to land acquisition. Rome.

Feichtner, I., Krajewski, M., and Roesch, R. (2019) Human Rights in the Extractive Industries. Berlin: Springer.

Flemmer, R. and Schilling-Vacaflor, A. (2016) 'Unfulfilled promises of the consultation approach: the limits to effective Indigenous participation in Bolivia's and Peru's extractive industries', Third World Quarterly, 37 (1), pp. 172-188.

Galtung, J. and Fischer, D. (2013) Johan Galtung. Berlin, Heidelberg: Springer.

GIZ. (n.d.) 'Implementación del derecho a la consulta previa de los pueblos indígenas como aporte a la prevención de conflictos'. Available at: www.giz.de/en/worldwide/36075.html. 
Global Witness. (2019) Enemies of the State? London.

Green, M. (2014) The Development State. Aid, Culture and Civil Society in Tanzania. Oxford: James Currey.

Groves, C. (2017) 'Emptying the future: On the environmental politics of anticipation', Futures, 92, pp. 29-38.

Haesbaert, R. (2013) 'Del mito de la desterritorialización a la multiterritorialidad', Cultura y Representaciones Sociales, 8 (15), pp. 9-42.

Hanna, P., Langdon, E.J., and Vanclay, F. (2016b) 'Indigenous rights, performativity and protest', Land Use Policy, 50, pp. 490-506.

Hanna, P., Vanclay, F., Langdon, E.J., and Arts, J. (2016a) 'Conceptualizing social protest and the significance of protest actions to large projects', The Extractive Industries and Society, 3 (1), pp. 217-239.

Helwege, A. (2015) 'Challenges with resolving mining conflicts in Latin America', The Extractive Industries and Society, 2 (1), pp. 73-84.

Holterman, D. (2014) 'Slow violence, extraction and human rights defence in Tanzania: notes from the field', Resources Policy, 40, pp. 59-65.

Huizenga, D. (2019) 'Governing territory in conditions of legal pluralism: Living law and free, prior and informed consent (FPIC) in Xolobeni, South Africa', The Extractive Industries and Society, 6, pp. 711-721.

Hundsbæk Pedersen, R. and Kweka, O. (2017) 'The political economy of petroleum investments and land acquisition standards in Africa: The case of Tanzania', Resources Policy, 52, pp. 217-225.

Instituto Interamericano de Derechos Humanos. (2016) 'La consulta previa, libre e informada. Una mirada crítica desde los pueblos indígenas', San José, Costa Rica. Available at: www.iidh.ed.cr/libroconsulta.

International Labour Organization. (1957). Indigenous and Tribal Populations Convention. Available at: www.ilo.org/dyn/normlex/en/f?p=NORMLEXPUB:12100:0::NO::P12100_ ILO_CODE:C107.

International Labour Organization. (2009) Indigenous and tribal people's rights in practice. A guide to ILO Convention NO. 169. Geneva.

International Labour Organization. (n.d.) 'Who are the Indigenous and tribal peoples?'. Available at: www.ilo.org/global/topics/indigenous-tribal/WCMS_503321/lang-en/index.htm.

Inkman, D., Cambou, D., and Smis, S. (2018) 'Evolving Legal Protections for Indigenous Peoples in Africa: some Post-UNDRIP Reflections', African Journal of International and Comparative Law, 26 (3).

Iturralde, F. (2015) 'Descolonización y colonialismo interno: Lugar y función de lo colonial', Bolivian Studies Journal, 21, pp. 40-60.

Jaskoski, M. (2020) 'Participatory Institutions as a Focal Point for Mobilizing: Prior Consultation and Indigenous Conflict in Colombia's Extractive Industries', Comparative Politics.

Le Billon, P. and Sommerville, M. (2017) 'Landing capital and assembling 'investable land' in the extractive and agricultural sectors', Geoforum, 82, pp. 212-224.

Leifsen, E., Gustafsson, M.T., Guzmán-Gallegos, M.A., and Schilling-Vacaflor, A. (2020) 'New mechanisms of participation in extractive governance: Between technologies of governance and resistance work', Third World Quarterly, 38 (5), pp. 1043-1057.

Llanes Salazar, R. (2020) 'La consulta previa como símbolo dominante: Significados contradictorios en los derechos de los pueblos indígenas en México', Latin American and Caribbean Ethnic Studies, 15 (2), pp. 170-194.

Machado, M., López Matta, D., Campo, M.M., Escobar, A., and Weitzner, V. (2017) 'Weaving hope in ancestral black territories in Colombia: The reach and limitations of free, prior, and informed consultation and consent', Third World Quarterly, 38 (5), pp. 1075-1091. 
McNeish, J.A. (2017) 'A vote to derail extraction: Popular consultation and resource sovereignty in Tolima, Colombia', Third World Quarterly, 38 (5), pp. 1128-1145.

Merino, R. (2018) 'Re-politicizing participation or reframing environmental governance? Beyond Indigenous' prior consultation and citizen participation', World Development, 111, pp. $75-83$.

Middeldorp, N. and Le Billon, P. (2019) 'Deadly environmental governance: Authoritarianism, eco-populism and the repression of environmental and land defenders', Annals of the Association of American Geographers, 109 (2), pp. 324-337.

Miller, R.J. (2015) 'Consultation or consent: The United States' duty to confer with American Indian governments', North Dakota Law Review, 91, pp. 37-98.

Mills, J. (2017) 'Destabilizing the Consultation Framework in Alberta's Tar Sands', Journal of Canadian Studies/Revue d'études canadiennes, 51 (1), pp. 153-185.

Mitchell, M.I. and Yuzdepski, D. (2019) 'Indigenous peoples, UNDRIP and land conflict: An African perspective', The International Journal of Human Rights, 23 (8), pp. 1356-1377.

Moore, M., von der Porten, S., and Castleden, H. (2017) 'Consultation is not consent: Hydraulic fracturing and water governance on Indigenous lands in Canada', WIREs Water, 4 (1180).

Navas, G., Mingorria, S., and Aguilar-González, B. (2018) 'Violence in environmental conflicts: the need for a multidimensional approach', Sustainability Science, 13 (3), pp. 649-660.

Nest, M. (2017) Preventing Corruption in Community Mineral Beneficiation Schemes. Bergen: U4/CMI.

Nixon, R. (2011) Slow Violence and the Environmentalism of the Poor. Cambridge, MA: Harvard University Press.

Orozco, Z.T. and Veiga, M. (2018) 'Locals' attitudes toward artisanal and large-scale mining-A case study of Tambogrande, Peru', The Extractive Industries and Society, 5 (2), pp. 327-334.

Padilla Rubiano, G.A. (2015) 'Los pueblos indígenas y la consulta previa: ¿Normatización o emancipación? Una mirada desde Guatemala’, Revista Colombiana de Sociología, 39 (1), pp. 193-219.

Pasternak, S. (2017) Grounded Authority: The Algonquins of Barriere Lake Against the State. Minnesota, MN: University of Minnesota Press.

Perreault, T. (2015) 'Performing participation: Mining, power, and the limits of public consultation in Bolivia', The Journal of Latin American and Caribbean Anthropology, 20 (3), pp. 433-451.

Peterson St-Laurent, G.P. and Le Billon, P. (2015) 'Staking claims and shaking hands: Impact and benefit agreements as a technology of government in the mining sector', The Extractive Industries and Society, 2 (3), pp. 590-602.

Prensa Comunitaria. (2017) 'Abelardo Curup, Murió en la Carcel en Resistencia contra una Empresa Cementer a'. Available at: www.prensacomunitaria.org/abelardo-curup-mur io-en-la-carcel-en-resistencia-contra-una-empresa-cementera1.

Rodrigo, D. and Amo, P.A. (2006). Background document on public consultation. Paris: OECD. Available at: www.oecd.org/mena/governance/36785341.pdf.

Rodriguez, A. (2009) El papel de la consulta previa en la pervivencia de los pueblos Indígenas y demás grupos étnicos de Colombia. Bogota: Universidad del Rosario.

Rodríguez-Garavito, C. (2011) 'Ethnicity.gov: Global governance, indigenous peoples, and the right to prior consultation in social minefields', Indiana Journal of Global Legal Studies, 18 (1), pp. 263-305.

Roesch, R. (2016) 'The story of a legal transplant: The right to free, prior and informed consent in sub-Saharan Africa', African Human Rights Law Journal, 16, pp. 505-531. 
Schilling-Vacaflor, A. and Flemmer, R. (2015) 'Conflict transformation through prior consultation? Lessons from Peru', Journal of Latin American Studies, 47 (4), pp. 811-839.

Sekar, N. (2016) 'Tigers, Tribes, and Bureaucrats: The voluntariness and socioeconomic consequences of village relocations from Melghat Tiger Reserve, India', Regional Environmental Change, 16 (1), pp. S111-123.

Simpson, L. (2017) As We Have Always Done: Indigenous Freedom Through Radical Resistance. Minnesota, MN: University of Minnesota Press.

Speed, S. (2017) 'Structures of settler capitalism in Abya Yala', American Quarterly, 69 (4), pp. 782-790.

Springer, S. and Le Billon, P. (2016) 'Violence and space: An introduction to the geographies of violence', Political Geography, 52, pp. 1-3.

Steinberg, J. (2016) 'Strategic sovereignty: A model of non-state goods provision and resistance in regions of natural resource extraction', Journal of Conflict Resolution, 60 (8), pp. 1503-1528.

Sterrit, A. (2019) 'When pipeline companies want to build on Indigenous lands, with whom do they consult?', CBC. Available at: www.cbc.ca/news/canada/british-columbia/ when-a-pipeline-wants-to-build-whose-in-charge-1.4971597.

Taylor, A. and Bonner, M.D. (2017) 'Policing economic growth: Mining, protest, and state discourse in Peru and Argentina', Latin American Research Review, 52 (1), pp. 3-17.

Temper, L. (2019) 'Blocking pipelines, unsettling environmental justice: From rights of nature to responsibility to territory', Local Environment, 24 (2), pp. 94-112.

Temper, L., Del Bene, D., and Martinez-Alier, J. (2015) 'Mapping the frontiers and front lines of global environmental justice: The EJAtlas', Journal of Political Ecology, 22 (1), pp. 255-278.

The WoMin Collective. (2017) 'Extractives vs development sovereignty: Building living consent rights for African women', Gender \& Development, 25 (3), pp. 421-437.

Torres-Wong, M.T. (2019) Natural Resources, Extraction and Indigenous Rights in Latin America: Exploring the Boundaries of Environmental and State-corporate Crime in Bolivia, Peru, and Mexico. Abingdon: Routledge.

United Nations. (2007) United Nations Declaration on the Rights of Indigenous Peoples. Geneva: UN.

United Nations. (2013) UN-REDD Programme. Guidelines on free, prior and informed consent. Geneva: UN.

Urkidi, L. (2011) 'The defense of community in the anti-mining movement of Guatemala', Journal of Agrarian Change, 11 (4), pp. 556-580.

Urteaga-Crovetto, P. (2018) 'Implementation of the right to prior consultation in the Andean countries. A comparative perspective', The Journal of Legal Pluralism and Unofficial Law, 50 (1), pp. 7-30.

Vermeulen, S. and Cotula, L. (2010) 'Over the heads of local people: consultation. Consent, and recompense in large-scale land deals for biofuels projects in Africa', The Journal of Peasant Studies, 37 (4), pp. 899-916.

Walsh, B., van der Plank, S., and Behrens, P. (2017) 'The effect of community consultation on perceptions of a proposed mine: A case study from southeast Australia', Resources Policy, 51, pp. 163-171.

Walter, M. and Urkidi, L. (2017) 'Community mining consultations in Latin America (20022012): The contested emergence of a hybrid institution for participation', Geoforum, 84, pp. 265-279.

Weitzner, V. (2002) Through Indigenous Eyes: Toward Appropriate Decision-making Processes Regarding Mining on or Near Ancestral Lands; Final Synthesis Report. Ottawa, ON: North-South Institute. 
Weitzner, V. (2019) 'Between panic and hope: Indigenous peoples, gold, violence(s) and FPIC in Colombia, through the lens of time', The Journal of Legal Pluralism and Unofficial Law, 51 (1), pp. 3-28.

Wildcat, M., McDonald, M., Irlbacher-Fox, S., and Coulthard, G. (2014) 'Learning from the land: Indigenous land based pedagogy and decolonization', Decolonization: Indigeneity, Education \& Society, 3 (3), pp. 1-15.

Wright, C. and Tomaselli, A. (2019) The Prior Consultation of Indigenous Peoples in Latin America: Inside the Implementation Gap. London: Routledge.

Xiloj, L. (2019) 'Implementation of the right to prior consultation of Indigenous Peoples in Guatemala' in Wright, C. and Tomaselli, A. (eds.). The Prior Consultation of Indigenous Peoples in Latin America: Inside the Implementation Gap. London: Routledge.

Youdelis, M. (2016) “"They could take you out for coffee and call it consultation!”: The colonial antipolitics of Indigenous consultation in Jasper National Park', Environment and Planning A, 48 (7), pp. 1374-1392.

Young, S. (2019) 'Indigenous Peoples, Consent and Rights. Troubling Subjects. Chapter 4: FPIC as National legislation' in The Philippines, the B'laan and the Tampaken Mine. Abingdon: Routledge.

Zaremberg, G. and Torres-Wong, M. (2018) 'Participation on the edge: Prior consultation and extractivism in Latin America', Journal of Politics in Latin America, 10 (3), pp. 29-58. 